EPRA International Journal of Economic and Business Review-Peer Reviewed Journal Volume - 10, Issue - 1, January 2022 | e-ISSN: 2347 - 9671| p- ISSN: 2349 - 0187

\title{
DYNAMIC PANEL APPROACH ON FOREIGN DIRECT INVESTMENT AND TERRORISM IN WEST AND CENTRAL AFRICA
}

\author{
Kabiru Alhaji ${ }^{1}$,Shehu Mohammed ${ }^{2}$, Sharehu Alhaji Muazu ${ }^{3}$ \\ ${ }^{1,2,3}$ Department of Economics, Shehu Shagari College of Education, Sokoto.
}

\begin{abstract}
DOI No: 10.36713/epra9400

Article DOI: $\underline{\text { https://doi.org/10.36713/epra9400 }}$

This study examined the connection between terrorism and foreign direct investment (FDI) inflow in the terrorised countries ofWest and Central Africa. The study used panel data of 12 West and Central African countries with issues of terrorism from 1999-2019, on the panel ARDL technique. From the results obtained, terrorism is found to discourages inflow of FDI in the sample countries. The study recommends that, countries concern shouldengage more security set ups in order to secure the environment for theeffective inflow of foreign direct investment.
\end{abstract}

KEYWORDS: foreign direct investment, terrorism, panel data

\section{INTRODUCTION}

Foreign Direct Investment (FDI) is a central factor in the development of economy and is thus, a key element of the economic growth of developing economies. As an important tool for growth and development, the worth of FDI for the economic growth is clear(Alzaidy et al., 2017). Initially, FDI was not regarded as a positive factor, rather as a factor that denied national sovereignty, social security, and domestic market in the developing world, especially in Sub-Saharan Africa (Abbes et al., 2015). The changes in perceptionson foreign direct investment have been attributed to global monetary policy, market globalization, and development. While taking investment decisions, foreign investors consider security as a major issue of great importance.

In Neoclassical base AK model, terrorism is accused of negating foreign direct investment(Aziz \& Khalid, 2017). The west and Central part of Sub-Saharan African countries are among developing countries that count much on the inflow of foreign direct investment. However, these set of countries are categorises among most terrorised countries in the world according to (Global Terrorism Index, 2019). A part from large number of terrorist attacks in the region, West and Central African states are among the most vulnerable countries with large number of death from terrorist attacks (Global Terrorism Index, 2020). Countries with high level of terrorism are bound to suffer the low influx of foreign capitals(Enders \& Sandler, 1996).

Although a surfeit of empirical worksconcerning the economic cost of terrorism have been studied since the September 11th attacks by likes ofEnders \& Todd, (1996), Mancuso, Cassandra\& Das(2010),Kinyanjui, (2014) andPowers \& Choi, (2012); they overlook the impact of terrorism on FDI inflow in West and Central Africa despite the menace of terrorism in the Africa's sub region. The very few that examines the nexus in the West and central Africalike Ezebuilo et al. (2019) and Haider \& Anwar (2014)concentrate on individual countries without concern to the panel of countries that suffers terrorist activities along their boarders. 
Moreover, despite the avowal that terrorism negate foreign investment inflow, the stylized fact gathered from the sample countries shows a positive relation between FDI inflow and terrorist attacks in the sample area, as shown in the figure1.

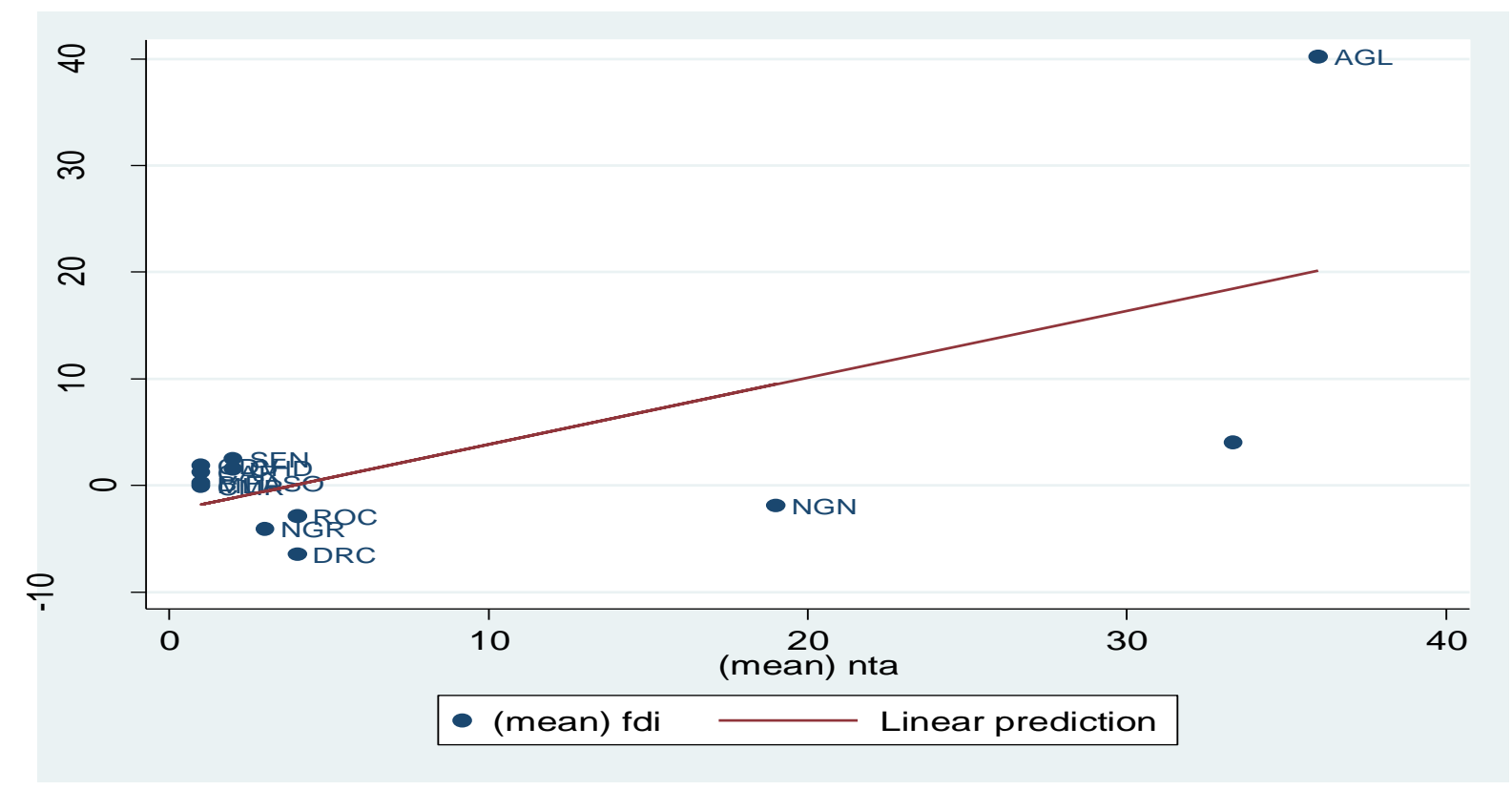

Figure 1Correlation between FDI and Number of terrorist attacks in the selected West and Central African Countries

Source: Authors calculation from (Global Terrorism Database, 2019; World Bank, 2020)

It is along this line that this study intends to examine the impact of terrorism on foreign direct investment in West and Central Africa.

This study contributed to the body of knowledge and policy making. Firstly, the present study contributes to the existing literature on foreign direct investment and terrorism. The study will contribute to the literature by exploring the impact of terrorism on foreign direct investment. The study is different from other studies as it analyses the number of terrorist attacks, in West and Central Africa, considering both domestic and transnational against previous studies that concentrated on transnational terrorism or single country. Secondly, this study will provide some insights on policy measures based on the empirical findings. By incorporating domestic and transnational terrorism, the clear picture of the impact of terrorism on FDI will be made known for effective policymaking.

\section{LITERATURE REVIEW}

The relationship between FDI and Terrorism is well documented in the literature. In the Neoclassical based theoretical structure (AK model), the goal of multinational firms is to maximise profit. FDI from Multinational firms is therefore basedon the productivity and costs of capital. The productivity of capital $(K)$ for firm is positivelyaffected by firm $i$ 's safe investment. Based on the AK Model, high level of terrorism discourages FDI inflow in the economy(Aziz \& Khalid, 2017; Lee, 2017).Empirically, Terrorism could negate the inflow of foreign direct investment in the countries with high terrorist activities. The literature shows that fear of the loss of investment and return to investment are main factors hindering the flow of foreign capitals in to terrorised states (Enders \& Todd, 1996; Lutz \& Lutz, 2006). Similarly, Omay, Araz-Takay, Aysegül, \& Kilic (2013) confirmed the negative impact of terrorism on FDI in Turkey. The linear and non-linear estimations' outcomes confirmed the negative effect of terrorism on Turkey's FDI inflow.

However, the negative impact is more severe during the high concentration of terrorism. Bandyopadhyay et al. (2014a) investigated the relationship between terrorism and FDI inflow. Terrorism is divided into domestic and transnational terrorism in the model. The study's outcome revealed that both domestic and transnational terrorism affected FDI inflow negatively during the study period. According to the study, the fear of the loss of investment may be the main reason behind the setback. In the African context, Ezeoha \& Ugwu (2015) found that conflicts negatively affected the inflow of foreign direct investment in Africa. The empirical study stated that the destruction of infrastructure in the affected areas is the major reason why investments coming from 
abroad are becoming lesser in the continent. The study revealed that, the impact was more severe in resourceabundant nations in Africa than in low resource-rich economies. In recollection Kinyanjui (2014), Bezi et al. (2016), Filer \& Stanišić (2016) and Galović et al. (2018) and also found a negative association between terrorism and FDI inflow. Similarly, Ezebuilo et al. (2019) found negative relationship between terrorism and FDI inflow in Nigeria. The studies attributed the setback to the risk attached to the capital invested in the terrorised zones.Contrarily, a study conducted by Powers \& Choi (2012) argued that non business related terrorism does not induce the same ramifications as business related terrorism; and thus, found that non-business related terrorism have little or less influence on acountry's FDI inflow.

\section{METHODOLOGY AND DATA}

Consistent with the AK model as in the empirical studies ofAziz \& Khalid (2017) and Lee (2017) and empirical studies of Bandyopadhyay et al., (2014); Kinyanjui, (2014) and Haider \& Anwar, (2014), this study adopted the following functional form.

$$
F D I=f(N T A, G D P G, M E X, M R T, T O)
$$

The function of foreign direct investment is transformed into the econometric model as:

$$
F D I_{i t}=\beta_{0}+\beta_{1} N T A_{i t}+\beta_{2} G D P G_{i t}+\beta_{4} M E X_{i t}+\beta_{5} M R T_{i t}+\beta_{6} T O_{i t}+e_{i t}
$$

where FDIrepresent the foreign direct investment inflow for the sampled countries, NTA is the number of terrorist attacks during the period. The GDP-growth is represented by GDPG. MEX is the military expenditure. The MRT signifies mineral rentsin the selected countries and TO is the trade openness.

\section{Data}

The datafor this study comprises panel data of 12 selected West and Central African countries from 1999 to 2019. The data for FDI \% of GDP is from world development indicators, data for the number of terrorist attacks (NTA) and death from terrorism DTA are sourced from (Global Terrorism Database, 2020). The data of military expenditure \% of GDP (MEX) is from the(Stockholm International Peace Research Institute (SIPRI), 2020). The data for NTA and DTA are transformed in log form. Data on the GDPG and mineral rent \% of GDP are obtained from(World Bank, 2020). The 23 countries include, Burkina Faso, Cameroon, Central African Republic, Chad, Cote'sd voire, Democratic Republic of Congo, Mali, Niger, Nigeria, Republic of Congo and Senegal. The countries are selected base onGlobal Terrorism Index, (2020) ranking as the most terrorized countries, most vulnerable, and the data availability. Moreover, these countries are facing the same type of terrorism as similar terrorist groups.

\section{Estimation procedure}

This research work is set to test for unit root, the panel ARDL's Mean Group (MG), Pooled Mean Group (PMG), and Dynamic Fixed Effect (DFE) estimators to assess the type of the relationship. These estimation techniques have the potential to address possible dynamic heterogeneous problems around the panel. The methods are advantageous since the panel techniques can be used if the variables are $\mathrm{I}(0)$ or $\mathrm{I}(1)$ or the combination of both. The models also have the ability to control endogeneity problem.

\section{RESULTS AND DISCUSSIONS}

The estimation procedure began with tests conducted to verify the series' normality and to ensure that no intense correlation (multi-collinearity) between the independent variables. The variables used, such as GDPgrowth, population, USAMEX and DTA in all the models show are normally distributed as shown in the See Appendix 1. Given the range of absolute values in all the correlation matrix, the study can confidently infer that there is no multicollinearity issue between our explanatory variables based on the thumb rule. This is because these values fall below the 0.80 benchmarks in line with (Prodan, 2013). See appendix 2. Given the long term covered, the unit root test must be carried out to determine the order in which the variables are integrated. Tables 1.1 reported the unit root tests using Levin Lin \& Chu, IM Pesaran Shin. ADF Fisher and PP Fisher indicate that the variables are a mixture of I(0) and I(1) suitable for the ARDL application panel. 
Table 1. 1 Unit root test results

\begin{tabular}{|c|c|c|c|c|c|}
\hline \multirow[t]{2}{*}{ Variables } & \multirow[t]{2}{*}{ Statistics } & \multicolumn{2}{|c|}{ Level I(O) } & \multicolumn{2}{|c|}{ First difference I(1) } \\
\hline & & Constant & $\begin{array}{l}\text { Constant \& } \\
\text { Trend }\end{array}$ & Constant & $\begin{array}{l}\text { Constant \& } \\
\text { Trend }\end{array}$ \\
\hline \multirow[t]{7}{*}{ FDI } & LLC & $\begin{array}{l}-3.7895 \\
(0.0001) * * *\end{array}$ & $\begin{array}{l}-3.9604 \\
(0.0000) * * *\end{array}$ & $\begin{array}{l}-6.5985 \\
(0.0000) * * *\end{array}$ & $\begin{array}{l}-3.9673 \\
(0.0000) * * *\end{array}$ \\
\hline & IPS & -2.2661 & -2.2941 & -8.1510 & -5.7049 \\
\hline & & $(0.0039) * *$ & $(0.0109)^{* *}$ & $(0.0000) * * *$ & $(0.0000)^{* * *}$ \\
\hline & FDF & -3.6489 & -2.8432 & -12.1963 & -6.7552 \\
\hline & & $(0.0000)^{* * *}$ & $(0.0260)^{* *}$ & $(0.0000)^{* * *}$ & $(0.0000)^{* * *}$ \\
\hline & FPP & -7.7980 & -8.8099 & -34.2801 & -29.4304 \\
\hline & & $(0.0000)^{* * *}$ & $(0.0000) * * *$ & $(0.0000) * * *$ & $(0.0000)^{* * *}$ \\
\hline \multirow[t]{8}{*}{ MEX } & LLC & -1.8723 & 0.0912 & -3.8025 & -2.9959 \\
\hline & & $(0.9694)$ & $(0.5363)$ & $(0.0001)^{* * *}$ & $(0.0014)^{* *}$ \\
\hline & IPS & 0.2978 & 0.4686 & -6.4593 & -5.1832 \\
\hline & & $(0.6171)$ & $(0.6803)^{* * *}$ & $(0.0000) * * *$ & $(0.0000)^{* * *}$ \\
\hline & FDF & 0.2894 & 0.1692 & -9.3408 & -6.0611 \\
\hline & & $(0.6134)$ & $(0.5669)$ & $(0.0000)^{* * *}$ & $(0.0000)^{* * *}$ \\
\hline & FPP & -6.0501 & -5.4114 & -24.7037 & -22.7601 \\
\hline & & $(0.0000)^{* * *}$ & $(0.0002) * * *$ & $(0.0000) * * *$ & $(0.0000)^{* * *}$ \\
\hline \multirow[t]{8}{*}{ NTA } & LLC & -0.7263 & -0.9214 & -6.8613 & -5.9494 \\
\hline & & $(0.7662)$ & $(0.1784)$ & $(0.0000) * * *$ & $(0.0000) * * *$ \\
\hline & IPS & 1.5533 & -0.2851 & -7.2257 & -5.7559 \\
\hline & & $(0.9398)$ & $(0.3878)$ & $(0.0000) * * *$ & $(0.0000) * * *$ \\
\hline & FDF & 0.1460 & -1.6416 & -10.1969 & -8.1008 \\
\hline & & $(0.5578)$ & $(0.0530)^{*}$ & $(0.0000)^{* * *}$ & $(0.0000)^{* * *}$ \\
\hline & FPP & -1.1776 & -3.1612 & --21.0550 & -17.8270 \\
\hline & & $(0.1218)$ & $(0.0012) * * *$ & $(0.0000)^{* * *}$ & $(0.0000)^{* * *}$ \\
\hline \multirow[t]{8}{*}{ GDPG } & LLC & -4.8453 & -4.9774 & -7.5530 & -5.1461 \\
\hline & & $(0.0000)^{* * *}$ & $(0.0000) * * *$ & $(0.0002)^{* * *}$ & $(0.0000)^{* * *}$ \\
\hline & IPS & -3.9401 & -3.4753 & -9.4532 & -7.1657 \\
\hline & & $(0.0000)^{* * *}$ & $(0.0003)^{* * *}$ & $(0.0000) * * *$ & $(0.0000)^{* * *}$ \\
\hline & FDF & -12.8379 & -5.0057 & -4.1798 & -13.9525 \\
\hline & & $(0.0000)^{* * *}$ & $(0.0000)^{* * *}$ & $(0.0000) * * *$ & $(0.0000)^{* * *}$ \\
\hline & FPP & -12.6944 & -12.3448 & -41.6890 & -37.4497 \\
\hline & & $(0,0000)^{* * *}$ & $(0.0000)^{* * *}$ & $(0.0000) * * * *$ & $(0.0000)^{* * *}$ \\
\hline \multirow[t]{8}{*}{ MRT } & LLC & 0.6872 & 3.3686 & 0.3365 & 1.4991 \\
\hline & & $(0.7540)$ & $(0.9996)$ & $(0.0001)^{* * *}$ & $(0.0000)^{* * *}$ \\
\hline & IPS & 0.3034 & -2.5368 & -4.4538 & -3.5414 \\
\hline & & $(0.6930)$ & $(0.9437)$ & $(0.0000) * * *$ & $(0.0002)^{* * *}$ \\
\hline & FDF & -1.2756 & 0.4484 & -7.8603 & -9.1084 \\
\hline & & $(0.1041)$ & $(0.6721)$ & $(0.0000)^{* * *}$ & $(0.0000)^{* * *}$ \\
\hline & FPP & -1.6675 & -0.2943 & -17.2816 & -14.2968 \\
\hline & & $(0.0509) * *$ & $(0.3849)$ & $(0.0000)^{* * *}$ & $(0.0000)^{* * *}$ \\
\hline \multirow[t]{8}{*}{ TO } & LLC & -1.2418 & -2.6501 & -8.0549 & 7.0034 \\
\hline & & $(0.1071)$ & $(0.0040)^{* * *}$ & $(0.0000) * * *$ & $(0.0000)^{* * *}$ \\
\hline & IPS & -1.0526 & -0.4906 & -7.9404 & -6.7003 \\
\hline & & $(0.1463)$ & $(0.3119)$ & $(0.0000) * * *$ & $(0.0000)^{* * *}$ \\
\hline & FDF & -1.1175 & -0.5960 & -11.5320 & -9.8132 \\
\hline & & $(0.1340)$ & $(0.2766)$ & $(0.0000)^{* * *}$ & $(0.0000)^{* * *}$ \\
\hline & FPP & -1.3724 & -0.7570 & -16.7122 & -13.3299 \\
\hline & & $(0.0874)$ & $(0.2259)$ & $(0.0000)^{* * *}$ & $(0.0000)^{* * *}$ \\
\hline
\end{tabular}

Note: The figures outside parenthesis are the t-statics values while those in the parenthesis are p-values. $* * *$ and $* *$ represents $1 \%$ and $5 \%$ significant levels respectively.

The Estimations of PMG, MG, and DFE with the Hausman test results are made shown in Table 1.2 (model 1). The Hausman test Prob > chi2 for MG-PMG and DFE-PMG are 0.5247 and 0.9894 respectively, 
both are greater than 0.05 . Consequently, the Hausman test fail to oppose the long-run homogeneity constraint at significance levels, which approves the appropriateness of the PMG estimation. Thus, our focus shall be on PMG while discussing the result. The result also shows that the pooled error correction terms are dynamically stable in PMG, MG, and DFE estimations. The coefficients' values are $-0.218,-0.888$, and -0.340 for PMG, MG, and DFE respectively, both terms are significant at a 1 per cent level. These confirm the existence of a long-run relationship among the variables. However, the main emphasis is on the PMG, as designated by the Hausman Reports.

Presented in Table 1.2, the long-run coefficient for terrorist attacks in the PMG estimation is negative and significant at the 5 per cent level. Although, the short-run coefficient of NTA is negative but it is not significant determinant of FDI in short run. The finding is in line with our expectations and the empirical findings of Ezebuilo et al. (2019), Haider \& Anwar (2014) Kinyanjui (2014) Nikši et al. (2019) and Omay et al. (2011) that terrorist attacks negates the flow of foreign direct investments. The outcome could be attributed to the fear loss of investment in the terrorised economy. Other explanatory variables in the PMG model are GDPgrowth (GDPG) and military expenditure (MEX) as a percentage of GDP. As earlier expected, GDPG portrays a positive impact on FDI inflow in these panels of countries. The coefficient values of GDPG are positive and significant at the 5 per cent level both in long-run and short-run periods. Meaning that the GDP-growth facilitates the inflow of the FDI in the region. It may well be attributed to market size growth as represented by GDP per-capita (Boateng, Hua, Nisar, \& Wu, 2015; Mah, 2010; Suleiman; Kaliappan, \& Ismail, 2015).

The coefficients for military (MEX) are not significant determinants of FDI inflow, both in long-run and short-run period of analysis. This contradict the Keynesian's and neoclassical's view but in line with (Habibullah et al., 2008; Kollias \& Paleologou, 2010). The factor variable representing raw-materials in the model is the mineral rent (MRT); its long-run coefficient in the PMG estimation is found to have positive and significant effect on FDI at a 1 percent level. In the short-run, the variable is also found to be insignificantly positive. This clarifies the importance of mineral rent in attracting FDI in the region. It is in line with the finding of (Bokpin, Mensah, \& Asamoah, 2015). Suleiman et al. (2015) also reported a significant positive effect of natural resources on FDI. In Sub-Saharan Africa, mineral resources are the main factor attracting FDI inflow in the region (Bokpin et al., 2015). In line with our expectations, the trade openness (TO) also showed a positive sign at 1 percent level of significance in the long run. In the short term the trade openness is not significant determinant of FDI.

Table 1.2 Terrorized countries in West and Central Africa Dependent Variable FDI.

\begin{tabular}{|c|c|c|c|}
\hline Independent Variable & $\begin{array}{c}\text { MG } \\
\text { ARDL } 1,2,0,1,0,0\end{array}$ & $\begin{array}{c}\text { PMG } \\
\text { ARDL 1,2,0,0,0.0 }\end{array}$ & $\begin{array}{c}\text { DFE } \\
\text { ARDL } 1,2,1,0,0,0\end{array}$ \\
\hline \multicolumn{4}{|l|}{ Long-run coefficients } \\
\hline LNTA & $3.127(1.13)$ & $-0.200(-2.41) * *$ & $-4.448(2.72) * *$ \\
\hline GDPG & $2.131(-1.05)$ & $0.172(2.52) * *$ & $0.175(0.37)$ \\
\hline MEX & $-8.915(-0.46)$ & $0.578(1.26)$ & $-0.058(-0.02)$ \\
\hline MRT & $0.413(1.00)$ & $0.470(3.78) * * *$ & $-4.458(-0.46)$ \\
\hline TO & $-1.613(-1.30)$ & $0.160(7.47) * * *$ & $-0.172(1.98) *$ \\
\hline Speed of adjustment (ECT) & $-0.888(-5.34) * * *$ & $-0.218(-3.84) * * *$ & $-0.340(-4.91) * * *$ \\
\hline \multicolumn{4}{|l|}{ Short-run Coefficients } \\
\hline$\Delta$ LNTA & $-0.026(-0.04)$ & $-0.273(-0.56)$ & $0.102(0.38)$ \\
\hline$\Delta \mathrm{GDPG}$ & $0.252(0.67)$ & $0.192(2.46) * *$ & $0.403(3.11) * * *$ \\
\hline$\triangle \mathrm{MEX}$ & $1.750(0.90)$ & $-0.043(-0.93)$ & $-0.052(-0.05)$ \\
\hline$\Delta \mathrm{MRT}$ & $-7.141(-1.03)$ & $0.224(1.09)$ & $0.714(1.18)$ \\
\hline$\Delta \mathrm{T} 0$ & $0.335(1.36)$ & $0.040(0.45)$ & $0.067(0.72)$ \\
\hline CONSTANT & $3.720(2.37) * *$ & $0.940(3.56) * * *$ & $2.305(1.96) *$ \\
\hline Hausman Test & $4.17(0.5247)$ & \multicolumn{2}{|c|}{$1.57(0.9894)$} \\
\hline No. of countries & 12 & 12 & 12 \\
\hline Observations & 252 & 252 & 252 \\
\hline
\end{tabular}

Notes: The figures in parenthesis are the $\mathrm{z}$-values except those for Hausman Test which are p-values. ***, $* *$ and $*$ represent $1 \%, 5 \%$ and $10 \%$ levels respectively. 


\section{ROBUSTNESS CHECKS}

To examine the strength of the findings, we perfume a robustness check. The study estimated another model with the death from terrorist attacks (DTA) as a measure of terrorism incidence instead of number of terrorist attacks (NTA). The Hausman test result of the robust models also braced PMG, and therefore, the study reported PMG result. Table 1.3 presents the comparison of model 1 PMG(LNTA) and model 2: PMG(LDTA). The outcome revealed that all the PMG variables (DTA) are rightly signed as PMG(TER). Most notably, the long-run coefficient of military expenditure is appropriately signed and significant

Table. 1.3 Comparison of PMG (LNTA) and model 2 PMG (LDTA) results

\begin{tabular}{lll}
\hline Independent Variable & $\begin{array}{l}\text { PMG Model 1 (LNTA) } \\
\text { ARDL 1,2,0,0,0.0 }\end{array}$ & $\begin{array}{l}\text { PMG model 2 (LDTA) } \\
\text { ARDL 1,2,1,1,2,1 }\end{array}$ \\
\hline Long-run coefficients & $-0.200(-2.41) * *$ & $-0.439(-3.88) * * *$ \\
LNTA & $0.172(2.52) * *$ & $0.518(3.80) * * *$ \\
GDPG & $0.578(1.26)$ & $0.080(1.17)$ \\
MEX & $0.470(3.78) * * *$ & $0.181(2.35) * *$ \\
MRT & $0.160(7.47) * * *$ & $0.118(9.37) * * *$ \\
TO & $-0.218(-3.84) * * *$ & $-0.286(-2.11) * *$ \\
Speed of adjustment (ECT) & & \\
Short-run Coefficients & $-0.273(-0.56)$ & $0.600(0.70)$ \\
$\Delta$ LNTA/LDTA & $0.192(2.46) * *$ & $0.283(1.59)$ \\
$\Delta$ GDPG & $-0.043(-0.93)$ & $0.077(0.05)$ \\
$\Delta$ MEX & $0.224(1.09)$ & $-0.389(-1.49)$ \\
$\Delta$ MRT & $0.040(0.45)$ & $-0.095(-1.33)$ \\
$\Delta$ TO & $0.940(3.56) * * *$ & $-0.902(3.56) * * *$ \\
CONSTANT & 12 & 12 \\
No. of countries & 252 & 252 \\
Observations & & \\
\hline Not: The figurs & Z & \\
\hline
\end{tabular}

Notes: The figures in parenthesis are the $\mathrm{z}$-values except those for Hausman Test which are p-values. ***, ** and $*$ represent $1 \%, 5 \%$ and $10 \%$ levels respectively.

\section{CONCLUSION}

This study focuses on the impact of terrorism on FDI in the West and Central Africa. The secondary data for the study were sourced from various data banks. The study used Mean Group (MG), Pooled Mean Group (PMG) and Dynamic Fixed Effect to analyse the study. The Hausman test result supported PMG and thus the study reported PMG result. From the result obtained, terrorist attacks have shown a negative effect on FDI inflow in the study area. GDP-growth, mineral rent and trade openness are found to have positive impact o FDI inflow of the selected countries.One policy implication from the results of this study is that terrorism significantly negates FDI inflow in West and Central Africa. Hence, the need for urgent attention to forestall the danger terrorism. The relevant state agencies need to encourage security set-up in other to boost the flow of FDI in the affected countries

\section{REFERENCES}

1. Abbes, S. M., Mostéfa, B., Seghir, G., \& Zakarya, G. Y. (2015). Causal Interactions between FDI, and Economic Growth: Evidence from Dynamic Panel Co-integration. Procedia Economics and Finance, 23(October 2014), 276-290. https://doi.org/10.1016/S2212-5671(15)00541-9

2. Alzaidy, G., Naseem, M., Niaz, B., \& Lacheheb, Z. (2017). The Impact of Foreign-direct Investment on Economic Growth in Malaysia: The Role of Financial Development. 7(3), 382-388.

3. Aziz, N., \& Khalid, U. (2017). Armed Conflict, Military Expenses and FDI Inflow to Developing Countries. Defence and Peace Economics, 2694(October), 1-14. https://doi.org/10.1080/10242694.2017.1388066

4. Bandyopadhyay, S., Sandler, T., \& Younas, J. (2014). Foreign direct investment, aid, and terrorism. Oxford Economic Papers, 66(1), 25-50. https://doi.org/10.1093/oep/gpt026

5. Bezi, H., Galovi, T., \& Mi, P. (2016). The impact of terrorism on the FDI of the EU. Zb. Rad. Eko. Rij., 34(2), 912. https://doi.org/10.18045/zbefri.2016.2.333

6. Boateng, A., Hua, X., Nisar, S., \& Wu, J. (2015). Examining the determinants of inward FDI: Evidence from Norway. Economic Modelling, 47, 118-127. https://doi.org/10.1016/j.econmod.2015.02.018 
7. Bokpin, G. A., Mensah, Lord, \& Asamoah, M. E. (2015). Foreign direct investment and natural resources in Africa. Journal of Economic Studies, 42(4), 608-621. https://doi.org/10.1108/JES-01-2014-0023

8. Enders, W., \& Sandler, T. (1996). Terrorism and Foreign Direct Investment in Spain and Greece. Kyklos, 49(3), 331-352. https://doi.org/10.1111/j.1467-6435.1996.tb01400.x

9. Enders, W., \& Todd, S. (1996). Terrorism and Foreign Direct Investment in Spain and Greece. Kyklos, 49(3), 331-352.

10. Ezebuilo, R. U., Henry, T. Asogwa, Ozoemena, S. N., Ogbonna, \& Oliver, E. (2019). Impact of Terrorism on Foreign Direct Investment in Nigeria. The Impact of Global Terrorism on Economic and Political Development:, 335-247. https://doi.org/10.1108/978-1-78769-919-920191020

11. Ezeoha, A. E., \& Ugwu, O. J. (2015). The Interactive Impact of Armed Conflicts on Freign Direc Ivestments in Africa. CSAE 2015 Conference on Economic Development in Africa, March, 22-24.

12. Filer, R. K., \& Stanišić, D. (2016). The Effect of Terrorist Incidents on Capital Flows. Review of Development Economics, 20(2), 502-513. https://doi.org/10.1111/rode.12246

13. Galović, T., Bezić, H., \& Mišević, P. (2018). Terrorist activities and capital flows of developed countries. Acta Oeconomica, 68(3), 337-352. https://doi.org/10.1556/032.2018.68.3.2

14. Global Terrorism database. (2019) https://www.start.umd.edu/gtd/search/Results.aspx?search $=\&$ sa. $x=54 \&$ sa. $y=3$

15. Global Terrorism Index. (2019). Measuring the Impact of Terrorism. http://visionofhumanity.org/reports

16. Global Terrorism Index. (2020). Measuring the impact of Terrorism. Global Terrorism Index. http://visionofhumanity.org/reports

17. Habibullah, M. S., Law, S., \& Marikan, A. (2008). Defense spending and economic growth in Asian economies: A panel error-correction approach. MPRA Munich Personal RePEc Archive, 12105.

18. Haider, M., \& Anwar, A. (2014). Impact of terrorism on FDI flows to Pakistan. MPRA Munich Personal RePEc Archive, 57165.

19. Kinyanjui, S. (2014). The Impact of Terrorism on Foreign Direct Investment in Kenya. International Journal of Buiness Administration, 5(3). https://doi.org/10.5430/ijba.v5n3p148

20. Kollias, C., \& Paleologou, S. M. (2010). Growth, investment and military expenditure in the European Union-15. Journal of Economic Studies, 37(2), 228-240. https://doi.org/10.1108/01443581011043618

21. Lee, C. Y. (2017). Terrorism, Counterterrorism Aid, and Foreign Direct Investment. Foreign Policy Analysis, 13(1), 168-187. https://doi.org/10.1111/fpa.12087

22. Lutz, J. M., \& Lutz, B. J. (2006). International Terrorism in Latin America: Effects on Foreign Investment and Tourism. Journal of Social, Political, and Economic Studies, 31(3), 321-338.

23. Mah, J. S. (2010). Foreign direct investment inflows and economic growth of China. Journal of Policy Modeling, 32(1), 155-158. https://doi.org/10.1016/j.jpolmod.2009.09.001

24. Mancuso, Anthony; Cassandra, E Dirienzo Jayoti, D. (2010). Assessing Terrorist Risk and FDI Using Relative Information Measures. Applied Economics Letters, 17(8), 787-790.

25. Nikši, M., Daniel, D., \& Marina, B. S. (2019). Causality between Terrorism and FDI in Tourism : Evidence from Panel Data. Economies, 7(38). https://doi.org/10.3390/economies7020038

26. Omay, T., Araz-Takay, B., Aysegül, E., \& Kilic, I. (2013). The Effects of Terrorist Activities on Foreign Direct Investment: Nonlinear Evidence from Turkey. Review of Economics, 64(2), 139-158.

27. Omay, T., Araz, T., \& Ilalan, D. (2011). The effects of terrorist activities on foreign direct investment: nonlinear Evidence. In Munich Personal RePEc Archive (No. 31015; Issue 31015). https://mpra.ub.uni-muenchen.de/31015/

28. Powers, M., \& Choi, S. W. (2012). Does transnational Terrorism Reduce Foreign Direct Investment? BusinessRelated Versus Non-Business-related Terrorism. Journal Peace Researcheace Research, 49(3), 407-422. https://doi.org/10.1177/0022343312436768

29. Prodan, I. (2013). The effect of weather on stock returns: A comparison between emerging and developed markets. Anchor Academic Publishing (Aap_verlag).

30. Stockholm International Peace Research Institute (SIPRI). (2020). Military expenditure by country as percentage of gross domestic product, 1988-2019. https://www.sipri.org/sites/default/files/Data for all countries from 19882019 as a share of GDP.pdf

31. Suleiman, N. N., Kaliappan, S. R., \& Ismail, N. W. (2015). Determinants of foreign direct investment: Empirical evidence from Southern Africa Customs Union (SACU) countries. International Journal of Economics and Management, 9(1), 1-24.

32. World Bank. (2020). World Development Indicators. Data Bank. https://databank.worldbank.org/reports.aspx? source $=2 \&$ series $=$ 
APPENDIX 1: DESCRIPTIVE STATISTICS

\begin{tabular}{llllll}
\hline Variables & Observations & Mean & St. Deviation & Min. & Max. \\
\hline & & & & & \\
FDI & 252 & 3.94246 & 11.27507 & -0.3 & 98 \\
LNTA & 252 & 2.795556 & 1.699771 & 0 & 0 \\
GDPG & 252 & 2.494118 & 1.602905 & -36.4 & 33.6 \\
MRT & 252 & 1.542857 & 3.473759 & 0 & 20.5 \\
MEX & 252 & 1.830556 & 1.536845 & .2 & 17.3 \\
TO & 252 & 53.3127 & 16.6178 & \multicolumn{1}{c}{1} & 20.5 \\
\hline
\end{tabular}

APPENDIX 2: CORRELATION MATRIX

\begin{tabular}{lllllll}
\hline Variables & FDI & MEX & NTA & GDPG & EYS & MRT \\
FDI & 1.0000 & & & & & \\
NTA & 0.0874 & 1.0000 & & & & \\
GDPG & 0.1638 & -0.0444 & 1.0000 & & & \\
MRT & -0.0310 & 0.3695 & 0.0931 & 1.0000 & & \\
MEX & 0.2023 & -0.0677 & -0.0685 & -0.1875 & 1.0000 & \\
TO & -0.0661 & -0.0102 & 0.1467 & 0.2788 & 0.1642 & 1.000 \\
& & & & & & \\
\hline
\end{tabular}

